Article

\title{
Temperature Stability and Effectiveness of Plasma-Activated Liquids over an 18 Months Period
}

\author{
Evanthia Tsoukou 1, Paula Bourke 1,2,3 (1) and Daniela Boehm 1,* \\ 1 Environmental Sustainability and Health Institute and School of Food Science and Environmental Health, \\ Technological University Dublin, Dublin, Ireland; evanthia.tsoukou@tudublin.ie (E.T.); \\ paula.bourke@ucd.ie (P.B.) \\ 2 Plasma Research Group, School of Biosystems and Food Engineering, University College Dublin, \\ Dublin, Ireland \\ 3 School of Biological Sciences, Queens University Belfast, Belfast BT9 7BL, UK \\ * Correspondence: daniela.boehm@tudublin.ie
}

Received: 28 September 2020; Accepted: 23 October 2020; Published: 28 October 2020

check for updates

\begin{abstract}
Non-buffered plasma-activated liquids such as water and saline have shown bactericidal effects. In the present study, we investigated the anti-bacterial efficacy and stability of plasma-activated water (PAW) and plasma-activated saline (PAS), generated using a high voltage dielectric barrier discharge system. This study compares the potential of non-buffered plasma-activated liquids (PAL) for the inactivation of Staphylococcus aureus (S. aureus) and Escherichia coli (E. coli) after storage of the solutions at five different temperatures for a storage time up to 18 months after their generation. The temperatures used were room temperature, $4{ }^{\circ} \mathrm{C},-16^{\circ} \mathrm{C},-80^{\circ} \mathrm{C},-150^{\circ} \mathrm{C}$. Both PAW and PAS achieved $6 \log$ reduction for both bacteria on the first day of their generation after 60 min contact time and they retained these effects after 18 months when stored at the lowest temperatures. Chemical analysis of PAL showed that plasma caused a drop in $\mathrm{pH}$, generation of reactive oxygen species and nitrates, whereas no nitrites are detected in the system used. The concentrations of chemical species were affected by the storage at different temperatures and a thermocouple probe was used to investigate the freezing behaviour of the PAL.
\end{abstract}

Keywords: plasma activated liquids (PAL); plasma activated water (PAW); plasma activated saline (PAS); storage; temperature stability; ROS; RNS

\section{Introduction}

The threat of antibiotic resistance has attracted a lot of interest in the 21st century, thus leading to antimicrobial stewardship programs and research on alternative antimicrobial therapies, as existing antibiotics are becoming a limited resource. Conversely, significantly less consideration has been given to the directly related issue of resistance toward antiseptics and biocides [1]. Many pathogens are becoming resistant to conventional sanitizing agents such as chemical compounds like quaternary ammonium compounds, chlorine and oxidizing components which are used in order to protect fresh produce from microbes and extend their life cycle [2], but also in the biomedical sector where bacterial resistance toward triclosan, chlorhexidine and quaternary ammonium compounds has been reported [3-5]. Consequently, there is a need for an "antiseptic stewardship" initiative and for effective disinfection methods in a variety of sectors. Such technology should be sustainable in terms of energy efficiency, and safe for both human and environment.

Atmospheric cold plasma processing techniques have gained importance among researchers during the last decade, particularly for antimicrobial applications. Plasma discharge generates an array of reactive chemical species which give it a great potential to address issues mentioned above. 
Apart from its bactericidal properties, atmospheric cold plasma has been reported to have controlled cytotoxic effects [6], degrade pesticides residues [7] and antibiotics in water [8].

Plasma-activated liquids (PAL) result from the exposure of liquids to a plasma discharge either directly, where the discharge happens inside or in contact with the liquid or indirectly through exposure to the plasma afterglow. Recent research has reported that PAL can efficiently inactivate a wide variety of microorganisms, including natural microflora in food produce [9], bacteria [10], spores [11], biofilms [12] and viruses [13]. It is generally agreed that the bactericidal activity of PAW derives from the combined action of a high positive oxidation reduction potential, acidic $\mathrm{pH}$ and generation of reactive chemical oxygen and nitrogen species [14]. PALs' microbial inactivation is attributed to oxidative damage of cell membrane, breakdown of cell wall, cell shrinkage and cytoplasmic leakage, and DNA breakdown [15]. PAL can overcome the limitations of direct exposure to plasma by offering advantages such as no damage to contaminated surfaces and biological materials, resulting from the electric field and charged particles, UV, and electrons. PAL also offer storability, they are easy to use, based on inexpensive resources and may be safer compared with alternative chemical sanitizers, such as chlorine-based products which are associated with risks of carcinogenic by-product formation [16].

In the liquid phase, reactive species with a relatively long lifetime, such as hydrogen peroxide, nitrites, and nitrates, are produced by plasma-liquid interactions. In addition to these species other potentially less stable reactive species with different concentrations that vary depending on the target liquid type are important for the biological effects. Hydrogen peroxide is an end-product of more complex reactions with the participation of other reactive oxygen species [17]. Reactive species generated in the liquid during plasma treatment can react to secondary products post-discharge. High concentration of nitrites and hydrogen peroxide are thought to be important for the antibacterial activity, through the creation of reactive chemical species, such as peroxynitric acid [18]. The post-discharge reactions between nitrites and hydrogen peroxide occurring in PAW can result in the generation of peroxynitrite/peroxynitrous acid, which significantly participates in the bactericidal effects of PAW [19].

Storage conditions are important factors affecting the chemical composition and antimicrobial potential of PAL, but little information has been published about PALs' stability over extended storage periods. The stability of the reactive species in solution is one of the most important issues to determine the inactivation effectiveness and shelf-life of PAL. Studies using different gases and plasma systems have shown that the PAL chemistry of long-lived chemical species can be kept stable for up to a period of 30 days after the generation of the solution [20,21]. Plasma-treated water has been shown to retain its antibacterial activity for 7 days [22] when stored at room temperature or a fridge. PAW stored at $-80^{\circ} \mathrm{C}$ caused approximately $4 \log$ microbial load reduction 30 days after its generation, with nitrites and hydrogen peroxide contributing synergistically to microbial inactivation [23].

The effectiveness of disinfectants against microbial cells is multifactorial and includes: (a) interaction of the active ingredients with organic matter, (b) general stability, (c) low temperature activity and (d) activation energy [24]. Bacterial susceptibility to disinfectants is influenced by the organisms' surface composition and contact times with the disinfectants. The species and genus of the test organism are also of great relevance. The interplay of these factors is of utmost importance for the degree of efficiency in accomplishing either disinfection or sterilization processes.

In our previous study we have reported that PAW and PAS can maintain their antimicrobial activity against $E$. coli and S. aureus for several days [25]. The current work constitutes a follow-on study using the same plasma system with optimal treatment parameters for highest microbial inactivation, to establish the stability of these PAL over long-term storage and determine suitable storage conditions. The objective of this study is the evaluation of the physicochemical properties and bactericidal activities of PAW and PAS stored in sub-ambient temperatures at storage times up to 18 months against $E$. coli and S. aureus strains, in order to ensure effective disinfection. 


\section{Materials and Methods}

\subsection{Plasma Source and Sample Treatment}

For the generation of PAL, a high voltage dielectric barrier discharge (DBD) atmospheric cold plasma system custom built at Technological University Dublin was used (Figure 1). The DBD system has a maximum voltage output of $120 \mathrm{kV}_{\mathrm{rms}}$ at $50 \mathrm{~Hz}$ in air. The DBD system consists of two $15 \mathrm{~cm}$ diameter aluminium disk electrodes which are separated by a rigid polypropylene container $(310 \times 230 \times 22 \mathrm{~mm})$, which serves as a sample holder and as a dielectric barrier with wall thickness of $1.2 \mathrm{~mm}$. Below the top electrode there is a primary dielectric barrier, which is a $10 \mathrm{~mm}$ Perspex layer. The distance between the two electrodes was equal to the height of the container and the dielectric barrier. The voltage of DBD is transformed onto the top electrode, i.e., the top electrode is the main output voltage carrier, and the bottom is the ground electrode. This system was previously described and characterised in Moiseev et al. [26], Patil et al. [27] and Milosavljevic et al. [28].

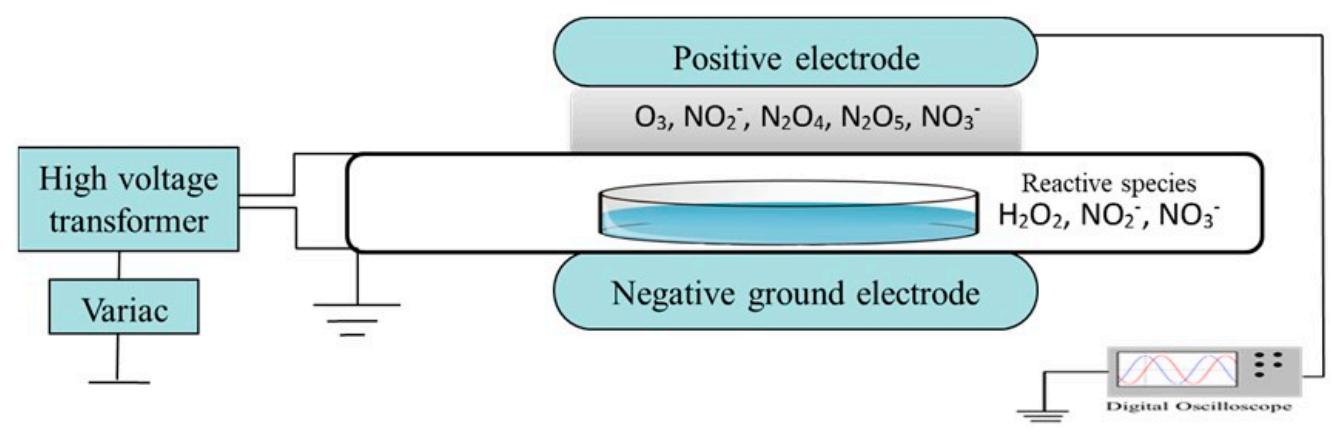

Figure 1. Schematic of the experimental setup of the dielectric barrier discharge plasma generator.

Liquid samples, i.e., $10 \mathrm{~mL}$ of distilled water or saline (137 $\mathrm{mM} \mathrm{NaCl}, 2.7 \mathrm{mM} \mathrm{KCl})$ were added separately to a sterile Petri dish of $90 \mathrm{~mm}$ diameter and placed without lid at the centre of the polypropylene plastic container and then sealed in a high barrier polypropylene bag (B2630, Cryovac, Charlotte, NC, USA). The plastic containers were placed at the centre between the electrodes of the DBD system and treated for $10 \mathrm{~min}$ at a voltage of $80 \mathrm{kV}_{\mathrm{rms}}$ and $50 \mathrm{~Hz}$ using atmospheric air as the inducer gas. In order to maximize the interaction of gas-phase plasma generated reactive species with the liquid, samples were stored at room temperature for $24 \mathrm{~h}$ post treatment storage time (PTST) in sealed conditions following the treatment times [29]. Liquids not exposed to plasma treatment were kept as negative controls ( $0 \mathrm{~min}$ ) and stored under the same conditions throughout the study. After $24 \mathrm{~h}$ PTST, $1.5 \mathrm{~mL}$ of PAW or PAS were transferred to sterile microtubes and stored at five different storage temperatures: room temperature, $4{ }^{\circ} \mathrm{C}$ (standard fridge, Zanussi, Dublin, Ireland), $-16{ }^{\circ} \mathrm{C}$ (standard freezer, Zanussi), $-80^{\circ} \mathrm{C}$ (ultra-low temperature freezer, Innova U535, Eppendorf New Brunswick, Hamburg, Germany) and $-150^{\circ} \mathrm{C}$ (cryogenic ultra-low temperature freezer, MDF-1156ATN, Sanyo, Osaka, Japan). After 1, 3, 6 and 18 months of storage period, the samples were thawed at room temperature, vortexed and tested for chemical composition and antimicrobial activity as described below. The samples were at room temperature when tested for all assays.

\subsection{Antimicrobial Efficacy}

\subsubsection{Bacterial Strains and Growth Conditions}

The bacterial strains Escherichia coli NCTC 12900 and S. aureus NCTC 1803 were obtained from the microbiology stock culture of the School of Food Science and Environmental Health of the Technological University Dublin and were maintained on tryptic soy agar (TSA, Biokar, Pantin, France). A single colony of the culture was used to inoculate the tryptic soy broth and incubated at $37^{\circ} \mathrm{C}$ for $18 \mathrm{~h}$. 


\subsubsection{Preparation of Cell Suspensions}

The cells were harvested by centrifugation at 10,000 rpm for $10 \mathrm{~min}$, washed in sterile phosphate buffered saline (PBS) and re-suspended in PBS. Finally, $30 \mu \mathrm{L}$ of bacterial suspension was diluted in $970 \mu \mathrm{L}$ of PBS and this was the bacterial working solution. To determine the antimicrobial effect for each plasma activated solution, $10 \%$ of the bacterial suspension was added to $90 \%$ PAL and incubated at room temperature for 15,30 or 60 min contact time as described previously [25].

\subsubsection{Microbiological Analysis}

After each contact time, a concentrated PBS $(4.5 \times$ PBS concentration) solution was added to the bacterial solution to neutralize the $\mathrm{pH}$ and cells were diluted in Maximum Recovery Diluent (MRD; Merck, Dublin, Ireland) [25]. Dilutions were made to $10^{-3}$ and three $10 \mu \mathrm{L}$ droplets were placed on TSA plates. The plates were incubated aerobically at $37^{\circ} \mathrm{C}$ for $24 \mathrm{~h}$, after which colonies were counted to determine the number of viable cells. In order to detect any subsequent increase in visible colonies, the plates were further incubated for 2 days. Results obtained are represented as surviving bacterial population in $\log _{10}$ colony forming unit (CFU)/mL units with error bars representing standard deviation.

\subsection{Investigation of the Chemical Composition of PAL}

\subsubsection{Determination of Hydrogen Peroxide and Reactive Oxygen Species (ROS)}

Hydrogen peroxide concentrations were quantified employing the titanium oxysulfate $\left(\mathrm{TiOSO}_{4}\right.$, Sigma-Aldrich, Arklow, Ireland) colorimetric method by incubating $10 \mu \mathrm{L} \mathrm{TiOSO}_{4}$ to $100 \mu \mathrm{L}$ of PAL in the dark for ten minutes producing the yellow pertitanic acid. The absorbance was measured at $405 \mathrm{~nm}$ using a spectrophotometric microplate reader.

The quantification of reactive oxygen species (ROS) concentrations in PAL were determined by oxidation of potassium iodide (KI, Sigma-Aldrich) to yellow iodine and spectrophotometric measurement. $50 \mu \mathrm{L}$ of PAL or $\mathrm{H}_{2} \mathrm{O}_{2}$ standard samples were added to $50 \mu \mathrm{L}$ of phosphate buffer solution $(10 \mathrm{mM})$ and $100 \mu \mathrm{L} 1 \mathrm{M}$ potassium iodide (Sigma-Aldrich) in a 96 well microtiter plate at room temperature, incubated for twenty minutes and the absorbance was read at $390 \mathrm{~nm}$ [20].

\subsubsection{Determination of Nitrite and Nitrate}

Concentration of nitrites was determined using Griess reagent (Sigma-Aldrich). A total of $50 \mu \mathrm{L}$ of Griess reagent was added to $50 \mu \mathrm{L}$ of PAL/ nitrite standard sample. Absorbance was read at $548 \mathrm{~nm}$, after $30 \mathrm{~min}$ of incubation, and compared to a sodium nitrite standard curve.

Nitrate concentrations were determined photometrically by 2,6-dimethyl phenol (DMP) using the Spectroquant ${ }^{\circledR}$ nitrate assay kit (Merck Chemicals, Darmstadt, Germany) adapted to a 96-well plate format. Sulfamic acid was used for pre-treatment of PAL for elimination of nitrite interference. $200 \mu \mathrm{L}$ of reagent $\mathrm{A}, 25 \mu \mathrm{L}$ of treated sample and $25 \mu \mathrm{L}$ reagent $\mathrm{B}$ was added into a microtube and incubated for $20 \mathrm{~min}$. After incubation period, $100 \mu \mathrm{L}$ of the total mixture was added to fresh 96 well microtiter plate and absorbance was read at $340 \mathrm{~nm}$ and compared to a sodium nitrate standard curve.

\subsection{3. $\mathrm{pH}$ and Temperature Measurements}

The $\mathrm{pH}$ of PAL was measured by an Orion $\mathrm{pH}$ meter (model 420A, Thermo Electron Corporation, Waltham, MA, USA). Temperature of samples before testing them was measured by non-contact infrared thermometer with laser pointer (N75KH, PrecisionGold, Dublin, Ireland). The temperature of samples during freezing was measured using a dual channel thermocouple data logger (Lascar Electronics, Wiltshire, UK) with measurements taken at $10 \mathrm{~s}$ intervals. 


\subsection{Data Analysis}

This research uses Excel (Microsoft, Redmond, WA, USA) and GraphPad Prism (GraphPad, San Diego, CA, USA) for plotting of data and statistical analysis (ANOVA).

\section{Results}

\subsection{Antimicrobial Effects}

The practical application of PAL in biomedical, food or processing sectors would benefit from an ability to generate these liquids off-site, and retention of functional stability over long-term storage. The effects of storage at different sub-ambient temperatures over periods of up to 18 months on the antibacterial effects were therefore investigated. PAW and PAS were the liquids of interest as they demonstrated high antimicrobial activity in our previous study [25] and present suitable liquids for a range of bio-decontamination applications. The antimicrobial effects and the chemical composition of four independent sets of PAW and PAS were analysed and two different scenarios were observed in the chemical measurements.

Our results showed that bactericidal stability of both PAL was affected by storage temperature. It is worthwhile to mention that when microbial inactivation was assessed, all PAL were completely thawed and at room temperature. The bactericidal stability of both PAL increased with lower storage temperature with $-150 \geq-80>-16>4 \geq 20^{\circ} \mathrm{C}$ showing a descending order for bacterial inhibition of E. coli and S. aureus, and solutions stored at RT or $4{ }^{\circ} \mathrm{C}$ showed complete loss of antibacterial activity (Figures 2-5).

As observed in previous experiments using same microbial targets, longer contact times (i.e., $60 \mathrm{~min}$ ) between bacteria and PAL were more effective compared to short contact time (i.e., 15 min showed very little antibacterial effect). The retention of antibacterial effect over storage time at different temperatures is presented for 60 min contact time in Figures $2-5$ with detailed data $(\log C F U / m L \pm S D)$ for all contact times available as tables in the Supplementary Data (Tables S1-S3). Untreated deionized water controls were stored at all of the storage temperatures and their average is represented in Figures 2-5.

Generally, antimicrobial efficacy of PAW and PAS was very similar and despite some experimental variability within sets, clear differences between different storage temperatures over time were apparent: Fresh PAW and PAS could cause a log reduction of up to 6 cycles for both bacteria tested (Figures 2-5). However, after a week of PAL storage at RT, $4,-16,-80$ or $-150{ }^{\circ} \mathrm{C}$ the bactericidal efficacy for some of the liquids decreased, particularly at the higher storage temperatures. PAW and PAS stored at RT and $4{ }^{\circ} \mathrm{C}$ no longer reduced bacterial growth. Conversely, PAW and PAS stored at $-80{ }^{\circ} \mathrm{C}$ and $-150{ }^{\circ} \mathrm{C}$ retained similar bactericidal efficacy to the fresh PAL and were able to inhibit bacterial growth after 60 min contact time (Figures 2-5). Specifically, after 1 week of storage, PAW that had been stored at $-16{ }^{\circ} \mathrm{C}$ could cause $3-4 \log$ reduction for $S$. aureus, whereas after 2 weeks the same solutions stored at these conditions did not inactivate the bacteria (Figure 4B). Regarding PAS in the same conditions, the solutions could cause a $6 \log$ reduction of $S$. aureus after 1 week of storage, declining to an approximate $2 \log$ reduction after 2 weeks (Figure 5B). With increasing storage time, the antimicrobial efficacy of PAL stored at $-16^{\circ} \mathrm{C}$ was lost and antimicrobial assay results after $1,3,6$ and 18 months of storage were quite similar for both bacteria. All PAL stored at $-80{ }^{\circ} \mathrm{C}$ and $-150{ }^{\circ} \mathrm{C}$ could still cause $6 \mathrm{log}$ reduction of bacterial concentrations. These findings indicate that PAW and PAS retained efficient content of reactive species after 18 months of storage time at $-80^{\circ} \mathrm{C}$ and $-150{ }^{\circ} \mathrm{C}$, and consequently bactericidal activity. However, bactericidal activity of these PAL was unstable at $-16^{\circ} \mathrm{C}$, with activity lost in the range of weeks. 


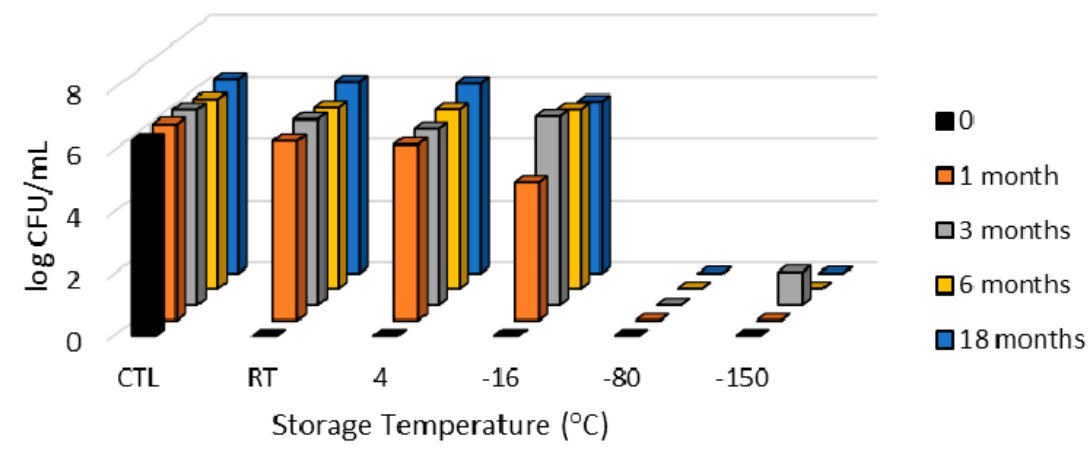

B

PAW S. aureus (60 min)

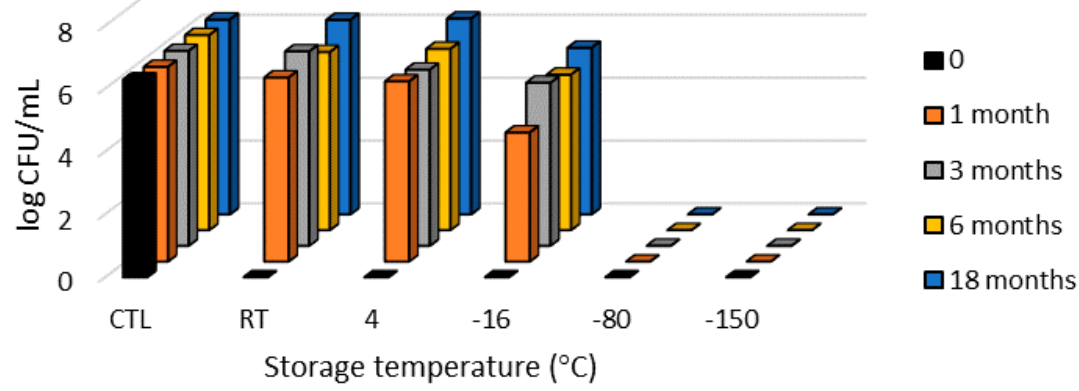

Figure 2. Microbial inactivation of E. coli and S. aureus at 60 min contact time, treated with PAW stored at different temperatures for up to 18 months. Graphs represent averages of two independent plasma treatments (Sets 1 and 2); standard deviations can be found in Supplementary Table S1. (A) PAW E. coli (60 min), (B) PAW S. aureus (60 min).

PAS E. coli (60 min)

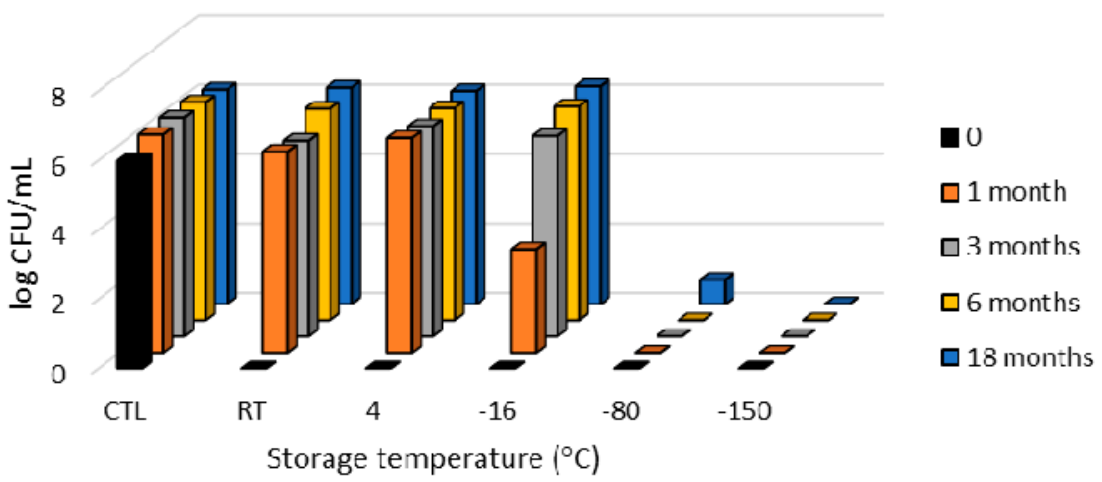

Figure 3. Cont. 


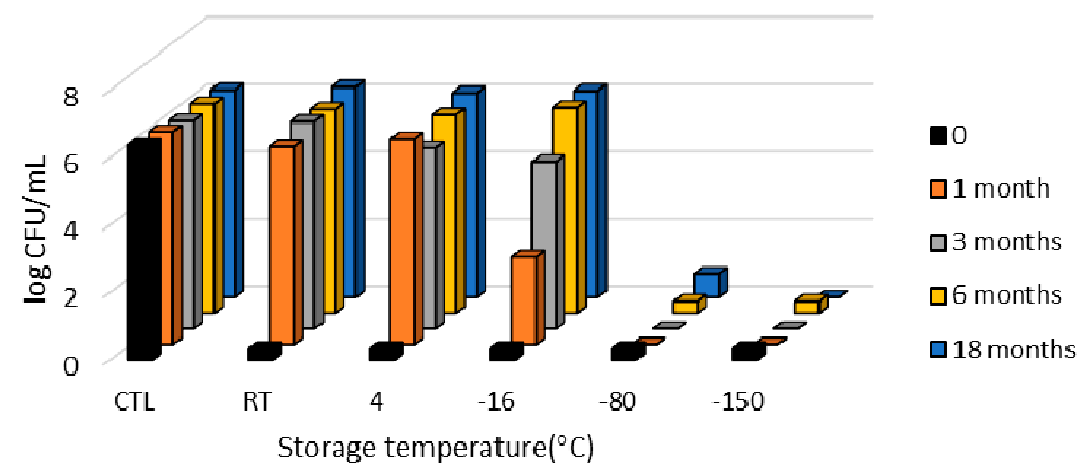

Figure 3. Microbial inactivation of E. coli and S. aureus at 60 min contact time, treated with PAS stored at different temperatures for up to 18 months. Graphs represent averages of 2 independent plasma treatments (Sets 1 and 2); standard deviations can be found in Supplementary Table S1. (A) PAS E. coli (60 min), (B) PAS S. aureus (60 min).

A PAW E. coli (60 min)

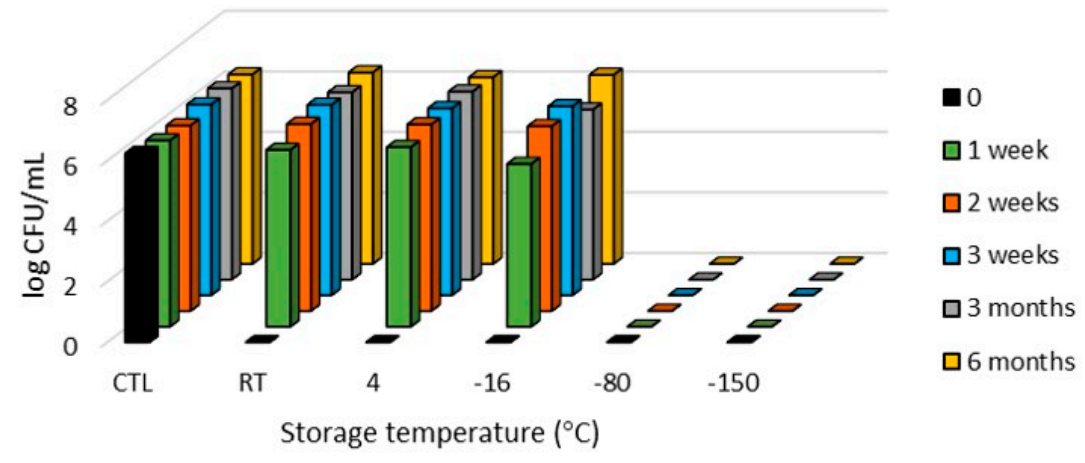

B

PAW S. aureus (60 min)

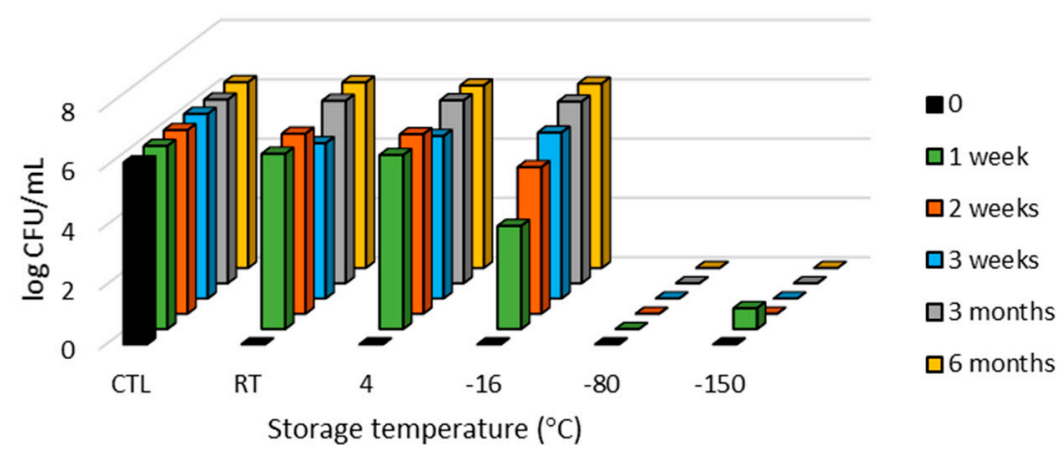

Figure 4. Microbial inactivation of E. coli and S. aureus at different contact times, treated with PAW stored at different temperatures for up to 6 months. (Set 4); standard deviations can be found in supplementary Table S3. (A) PAW E. coli (60 min), (B) PAW S. aureus (60 min). 


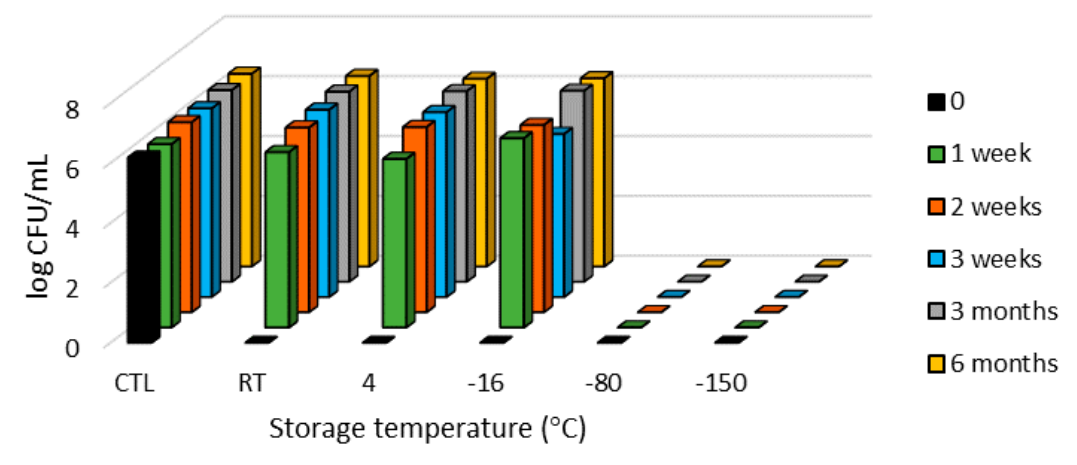

B

PAS S. aureus (60 $\mathrm{min})$

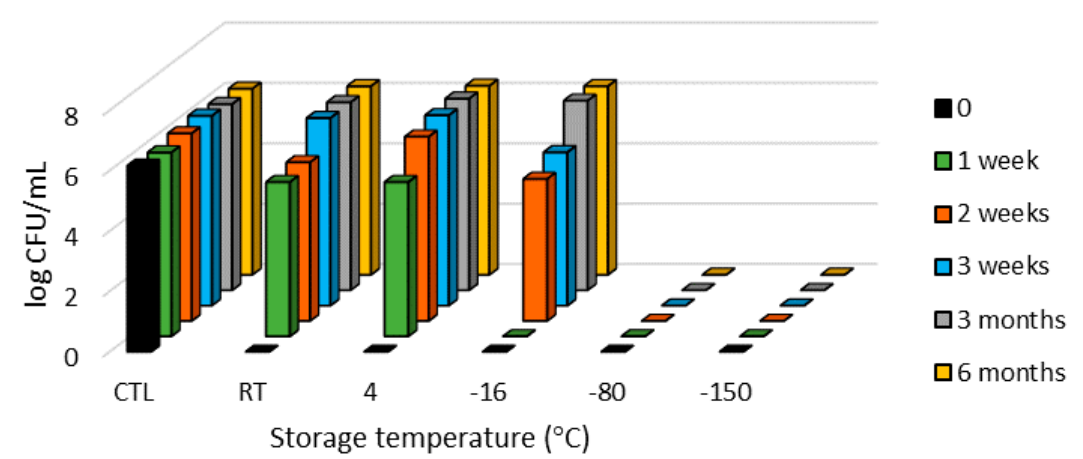

Figure 5. Microbial inactivation of E. coli and S. aureus at $60 \mathrm{~min}$ time, treated with PAS stored at different temperatures for up to 6 months (Set 4); standard deviations can be found in supplementary Table S3. (A) PAS E. coli (60 min), (B) PAS S. aureus (60 min).

\subsection{Chemical Characterisation of PAL}

Untreated PAL (controls) were stored in all different conditions and no difference was found between different storage times or storage temperatures (controls are not represented in the figures). Figure 6 shows the decline of $\mathrm{pH}$ of PAW and PAS (the first day of their generation) from 4.7 to 2.9 and from 4.7 to 3 , respectively, and $\mathrm{pH}$ appeared to be unaffected by storage in different ambient and sub-ambient temperatures, remaining stable during the storage time.

Generally, the chemical properties of PAW and PAS after storage in different storage conditions displayed changes when compared to freshly prepared solutions. The graphs below show the evolution of ROS and nitrate in PAW and PAS from the day of their generation over storage time (Figures 7 and 8) and were divided into four different phases. Phase I showed a strong decrease of ROS concentrations within the first month of storage in all conditions. In phase II (1-3 months) concentrations increased in sets 1 and 2 (scenario a) at all storage temperatures except $-16{ }^{\circ} \mathrm{C}$ while remaining constant in sets 3 and 4 (scenario b).

Phase III showed relatively stable concentrations of ROS, which decreased post 6 months of storage (phase IV only analysed for sets 1 and 2). ANOVA indicated that ROS concentrations were significantly affected by storage temperature and storage time ( 3 months and 6 months) by comparison with PAL stored at RT $(p<0.001)$. 


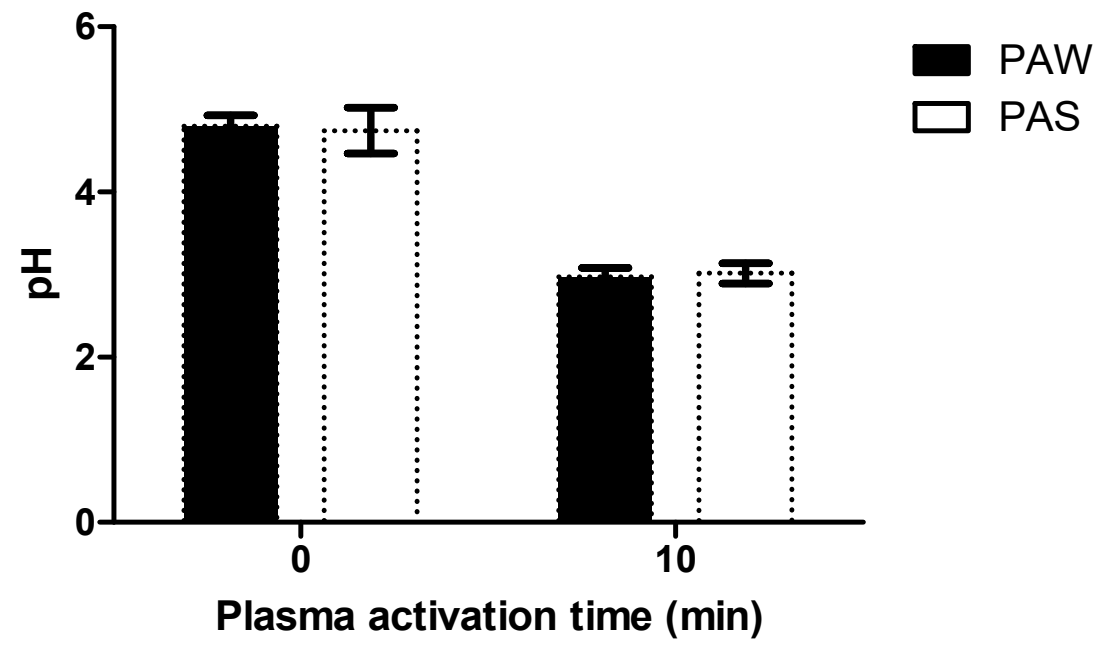

Figure 6. $\mathrm{pH}$ measurements of PAW and PAS the first day of their generation.

In sets 1 and 2 the concentration of ROS measured by KI the first day of PAL generation was around $1000 \mu \mathrm{M}$ for PAW and PAS. Both PAW and PAS experienced a decrease of ROS concentration over the storage at different storage temperatures over a period of a month (Figures 7 and 8). ROS concentration for both PAL after a month storage time varied between 300-700 $\mu \mathrm{M}$, except of PAL stored at $-16{ }^{\circ} \mathrm{C}$, which consistently had the lowest concentration around $200 \mu \mathrm{M}$. After 3 months of storage, measurements showed that ROS concentrations increased in all PAL, except for PAL stored at $-16^{\circ} \mathrm{C}$, which was the only liquid with unchanged concentration after 1 month storage. Highest concentration of ROS was observed for PAL stored at $20^{\circ} \mathrm{C}$ (room temperature) with a peak of around $1300 \mu \mathrm{M}$ for PAW, and $1500 \mu \mathrm{M}$ for PAS. Similar trend lines followed for measurements after 6 months storage time. ROS were also measured after 18 months of storage and all PAL had decreased ROS, similar to concentrations found after 1 month of storage. Regarding set 3 and set 4 , the starting concentrations of ROS were up to three times higher for PAW and up to 5 times higher for PAS (Figures 7 and 8). For this reason, hydrogen peroxide measurements were performed, which showed that only around $620-1000 \mu \mathrm{M}$ of the total $\sim 3000 \mu \mathrm{M}$ ROS in PAW from sets 3 or 4 were hydrogen peroxide (Figure 9). The measurements were repeated at 1, 2, 3 weeks and 1 month post storage for set 4 and showed a gradual decrease of ROS. This remained stable after 3 months of storage at the same conditions, similar to solutions in set 1 and set 2 . No changes were observed in hydrogen peroxide concentration (Figure 9).

Nitrite concentration was not detectable in any of the solutions. With regards to nitrate, plasma treatment increased PAW nitrate concentrations for set 1 and set 2 to around $600-800 \mu \mathrm{M}$ and for PAS to $500 \mu \mathrm{M}$ after $10 \mathrm{~min}$ plasma treatment (Figures 7 and 8 ). Nitrate concentrations were variable; in almost all sets concentrations increased after a month, and nearly doubled in some cases, with a following decrease after 3 months, and a subsequent gradual increase in concentration to 6 months of storage. As for storage temperature, no significant differences in nitrate concentrations among various storage conditions were obtained. Generally, PAL stored at RT had slightly higher nitrate concentrations for all storage times compared to other conditions. Set 3 and set 4 both showed higher concentrations of nitrate the first day of their generation for PAW, whereas PAS had lower concentration in set 3 but higher for set 4 . 

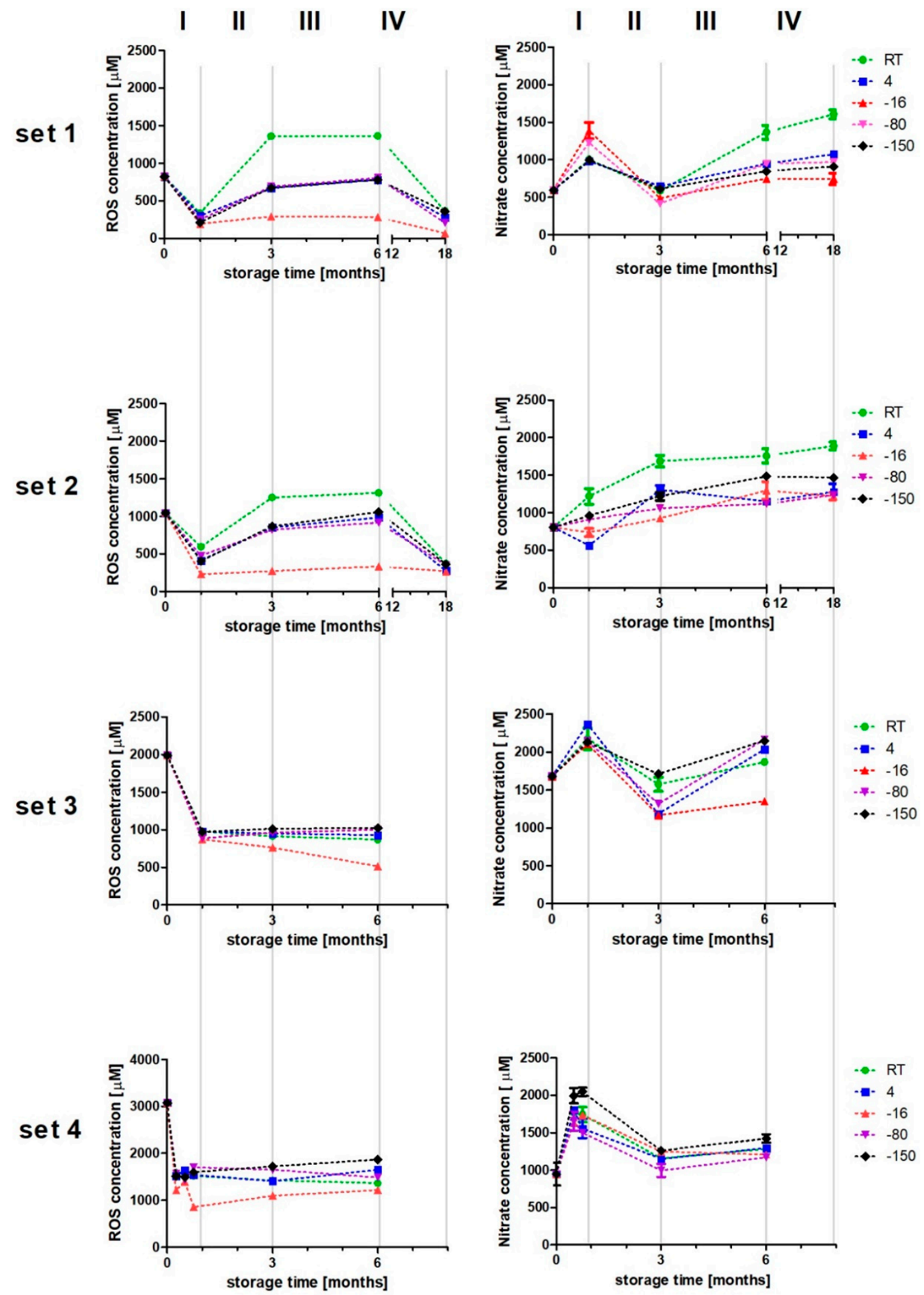

Figure 7. Chemical properties of PAW stored at different temperatures for 6-18 months showing ROS concentrations in the column on the left and nitrate concentrations in the column on the right. Samples were analysed after 1, 3 and 6 months and 18 months (sets 1 and 2). Set 4 was also analysed after 1, 2 and 3 weeks of storage. 

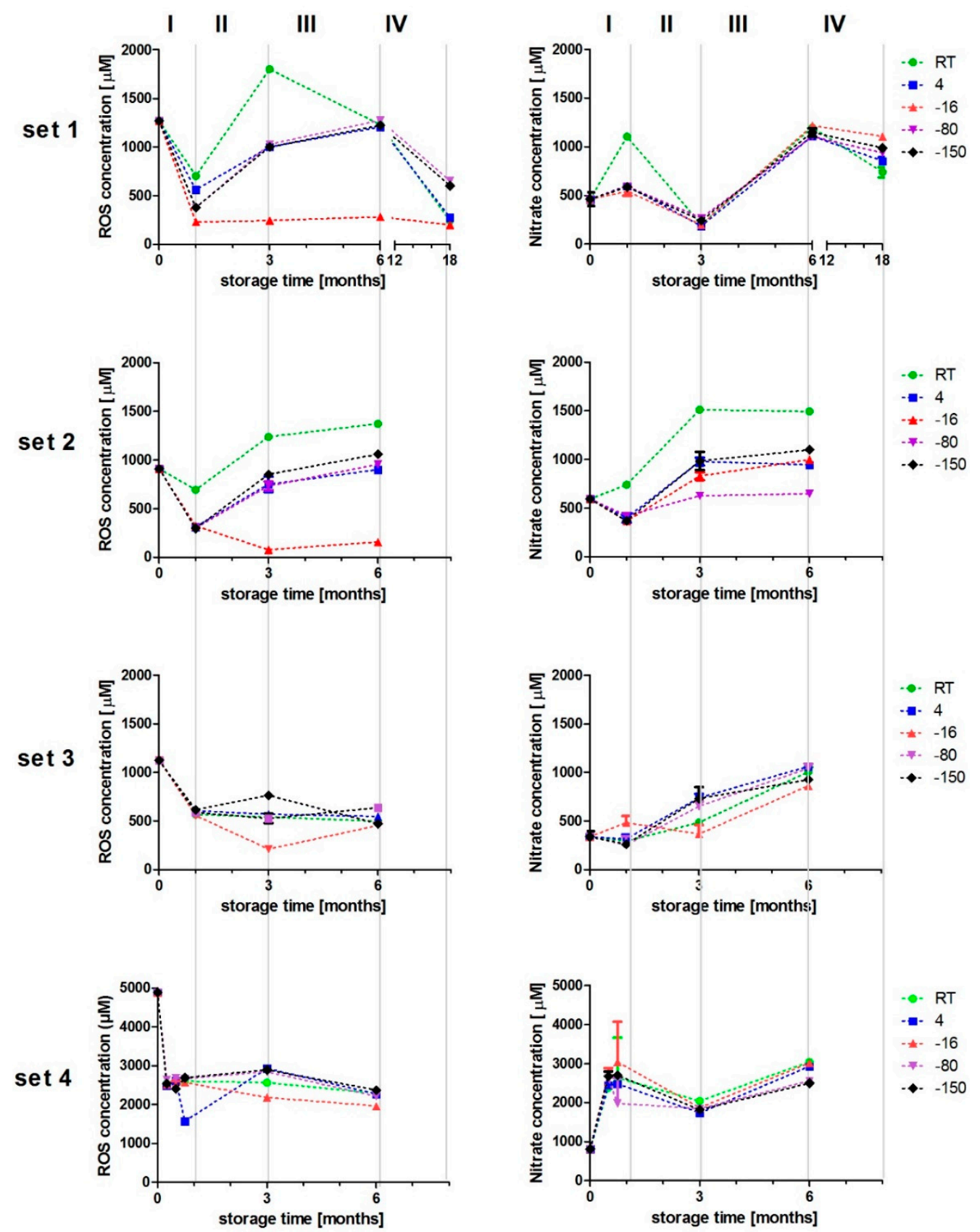

Figure 8. Chemical properties of four different sets of PAS stored at different temperatures for 6-18 months showing ROS concentrations in the column on the left and nitrate concentrations in the column on the right. Samples were analysed after 1, 3 and 6 months and 18 months (sets 1 and 2). Set 4 was also analysed after 1, 2 and 3 weeks of storage. 

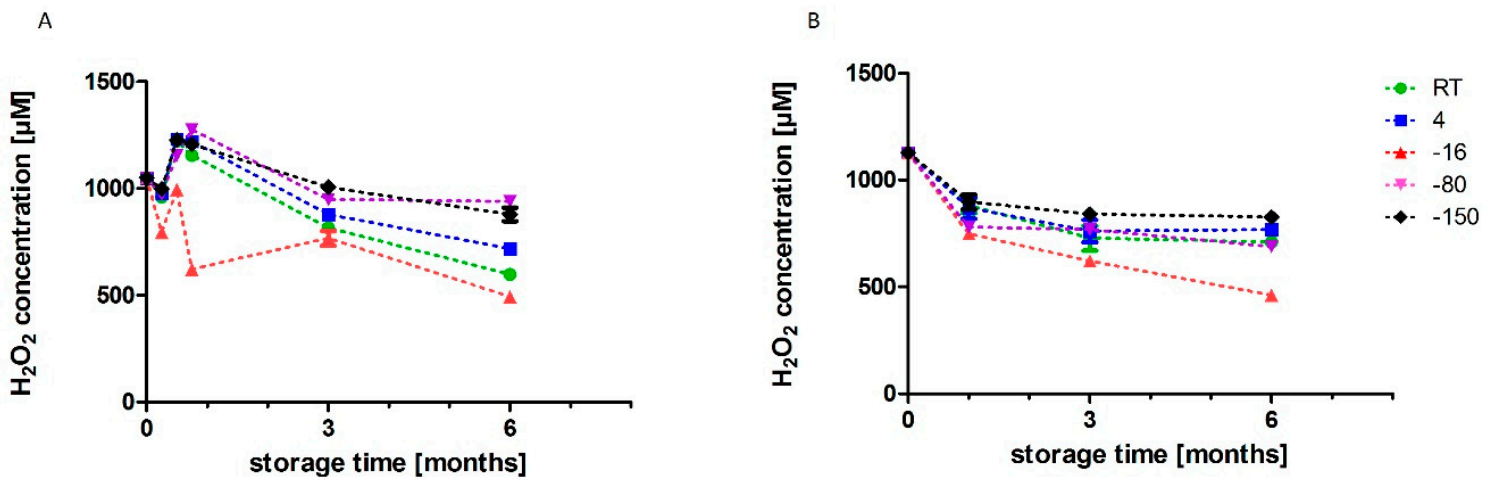

Figure 9. Hydrogen peroxide concentrations of PAW set 3 (A) and set 4 (B) stored at different temperatures for 6 months.

\subsection{Freezing Behaviour}

The instability of PAL during storage at $-16^{\circ} \mathrm{C}$ suggests a degradation of the relevant reactive species and differences to other conditions were observed in the chemical analyses. Freezing and nucleation behaviour of PAW stored at $-16^{\circ} \mathrm{C}$ was investigated in order to determine if the PAL stored at this temperature were fully frozen, or if they were still partly in aqueous phase. Generally, liquid freezing is usually divided into three stages as shown in Figure 10: (1) supercooling, (2) crystallization and (3) solid freezing. Generally, in the supercooling stage, nucleation of liquid may occur at any time. In the crystallisation phase, most of the solution turns into solid and during solid freezing the temperature of the solid solution drops until it reaches the end temperature. In this study, 3 sets of PAW were investigated and no major changes to nucleation and freezing points of PAW were observed with a nucleation point between -5.7 and $-4.8^{\circ} \mathrm{C}$ and a freezing point of -0.1 to $0{ }^{\circ} \mathrm{C}$ (Figure 11). Plasma reactive species did not show major effects on liquid supercooling and did not cause a depression of the freezing point. Of the samples analysed, one closely resembled deionised water in freezing behaviour, while the others were more closely aligned with the curves observed for solutions of $\mathrm{H}_{2} \mathrm{O}_{2}$ and $\mathrm{NaNO}_{3}$ at concentrations similar to those found in PAW. Differences to control water were seen in the crystallization phase where the temperature of PAW samples continuously decreased from the freezing point. This suggests the concentration of solutes in the aqueous phase as water froze out of solution.

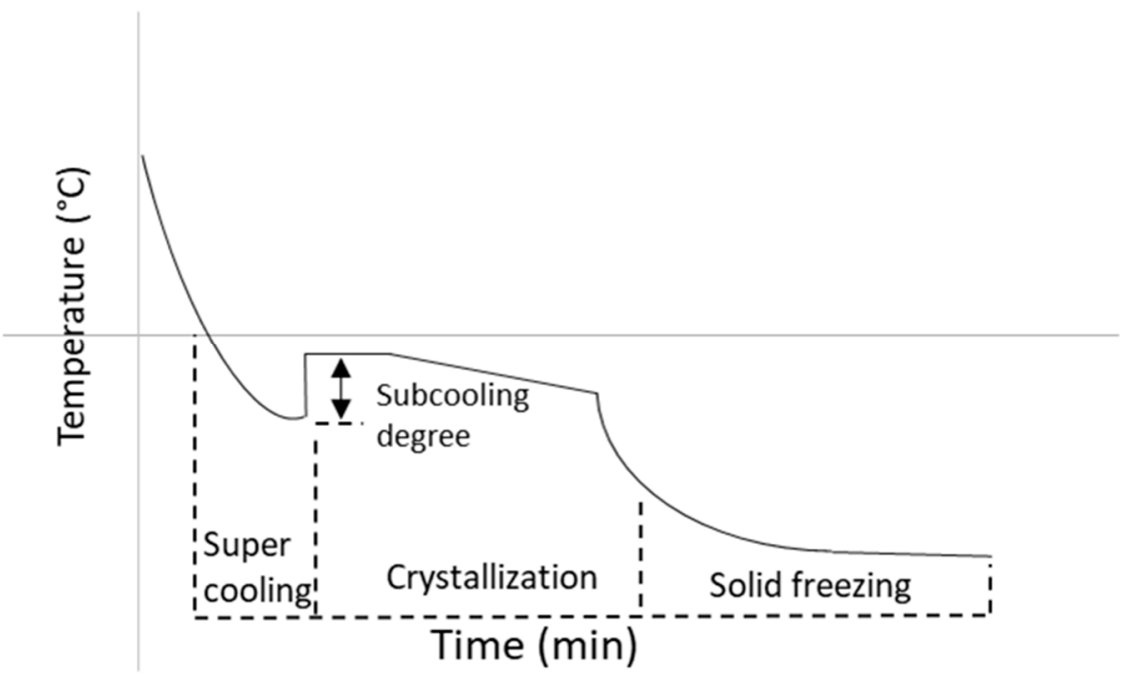

Figure 10. Schematic of typical freezing curve. 


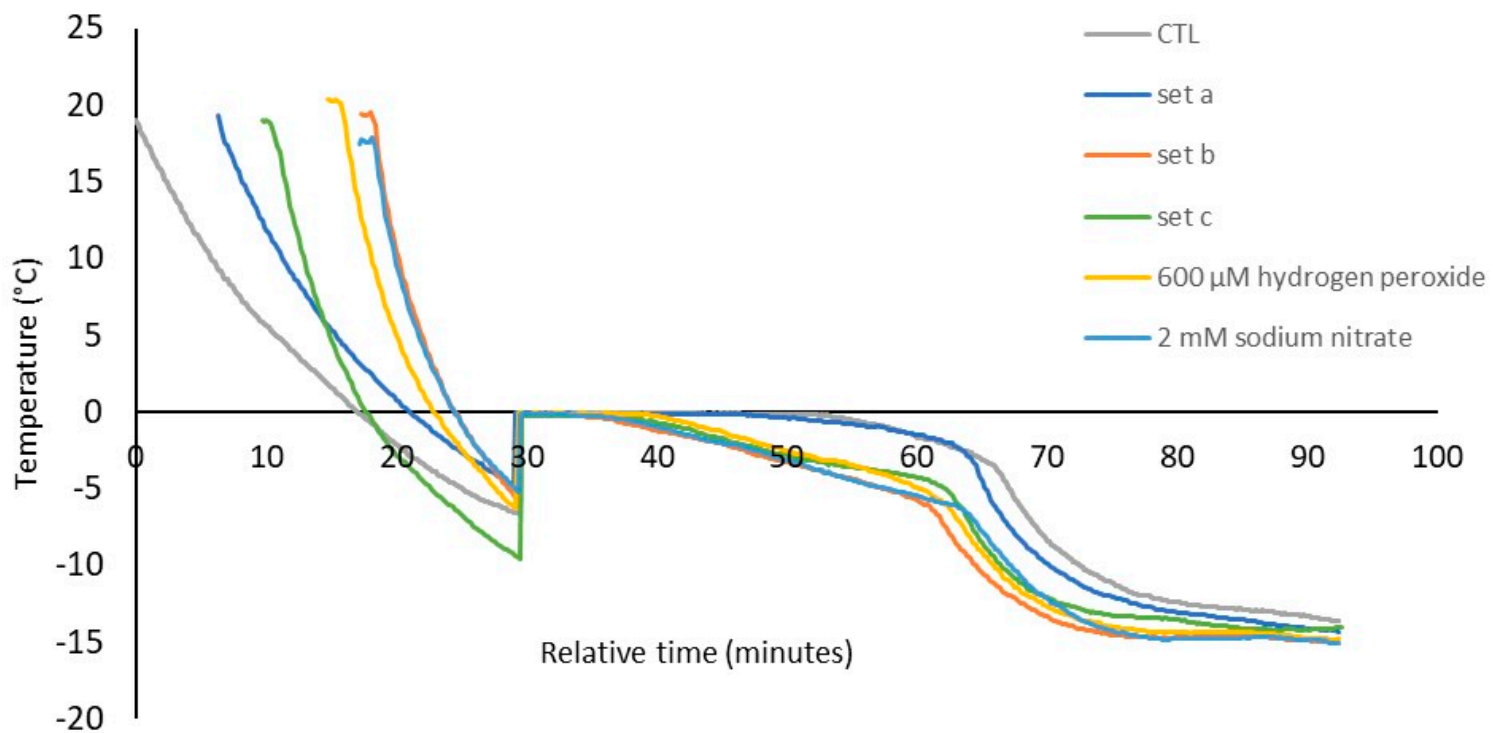

Figure 11. Freezing curve of PAW.

\section{Discussion}

The selection of the most suitable disinfectant and application conditions for maximum efficacy for a particular use, takes several important factors into consideration, amongst these are the active ingredient concentration in the solution, the required contact time and potential safety concerns. While PAL have shown promise as a new class of disinfectant solutions, their parity or superiority to conventional disinfectants needs to be demonstrable and explainable. The efficacy of PAL is dependent on many factors, such as the plasma system, plasma process parameters such as exposure time and post generation parameters such as the storage duration, the storage temperature, and the contact time with microbes. Our results revealed that the effect of storage temperature on preserving bactericidal activity of PAW and PAS was in the order of RT $<4<-16<-80$ equal to $-150^{\circ} \mathrm{C}$ (where storage at -80 and $-150{ }^{\circ} \mathrm{C}$ were the same for preservation of effect). The effects of the different storage conditions on PAL may be explained by differences in the physicochemical properties of PAL at different temperatures.

In the first scenario, ROS measurements showed a decrease after a month of storage time for all $\mathrm{PAL}$, an increase after 3 months and a decrease again at 18 months. These results indicate that ROS in PAL may continue to react with other chemical species such as RNS substances under these conditions. Bactericidal activity of PAL decreased with storage time for liquids stored at higher temperatures of $20{ }^{\circ} \mathrm{C}, 4{ }^{\circ} \mathrm{C},-16{ }^{\circ} \mathrm{C}$. Hydrogen peroxide is a strong oxidizer especially in acidic environments. The lowest concentration of ROS was always observed for PAW and PAS kept at $-16^{\circ} \mathrm{C}$. However, hydrogen peroxide concentrations were reasonably stable in all conditions. The liquids stored at higher temperatures than $-16{ }^{\circ} \mathrm{C}$, lost their antimicrobial activity completely after 1 month of storage time. The reduction in the concentration of ROS in PAL may be correlated with the loss of bactericidal efficacy observed. Interestingly PAW stored at $-80{ }^{\circ} \mathrm{C}$ and $-150{ }^{\circ} \mathrm{C}$ after 1 month $(306-360 \mu \mathrm{M})$, had ROS concentrations as low as PAW stored at $-16^{\circ} \mathrm{C}$ after 6 months $(307 \pm 29 \mu \mathrm{M})$ and it did not lose its bactericidal effects. However, these liquids still retained their efficacy against bacteria after 18 months of storage, demonstrating that the ROS measured here are not the only factors causing microbicidal effects.

ROS including superoxide, hydrogen peroxide, ozone, hydroxyl radical and singlet oxygen are chemically reactive and damaging species. Ozone is a gaseous oxidant that is widely applied in drinking water treatment and can be reasonably stable at $\sim \mathrm{pH} 3$ and ambient temperature in acid solutions [30]. According to Jablonowski et al. [31], the net production rate of the $\mathrm{O}_{3}$ deposited in buffered plasma activated media showed a saturation plateau, whereas in the gas phase the values were more than twice as high and did not reach a plateau. $\mathrm{O}_{3}$ is not formed in the liquid, it can only originate in the liquid phase through a limited solvation process from the gas phase. In our study, 
ozone was not measured directly but previous reports using the same in-package DBD system reported the generation of ozone in the gaseous phase at concentrations $>3000$ ppm after 10 min treatment [8] with no detectable ozone remaining after $24 \mathrm{~h}$ of storage [32], thus it is possible that ozone had solvated in PAL. The half-life of ozone in distilled water at $20{ }^{\circ} \mathrm{C}$ is generally considered to be from $20 \mathrm{~min}$ to $165 \mathrm{~min}$ [33] but can be longer at low temperature and low $\mathrm{pH}$. Some residual ozone in solution could be an explanation why the concentration of ROS was higher at the first day than following storage times. However, another study using the same plasma device and set-up was not able to detect dissolved ozone in plasma-treated solutions of antibiotics, where it was likely to have reacted immediately with the antibiotic molecules [8]. Ozone may lead to the formation of other reactive species by post exposure reactions in the liquid sample [34] and decomposition products such as hydroxyl radical can inactivate microorganisms.

The stability of reactive species during storage is important to maintain the bactericidal properties. The reduction of concentrations of hydrogen peroxide, nitrates and values of oxidation-reduction potential (ORP) have been proposed to affect microbial inactivation by PAW over storage time stored at $25{ }^{\circ} \mathrm{C}, 4{ }^{\circ} \mathrm{C}$ and $-20{ }^{\circ} \mathrm{C}$ [23]. In that study, PAW stored at $-80{ }^{\circ} \mathrm{C}$ was the only solution with stable hydrogen peroxide, nitrite concentrations and $\mathrm{pH}$, that retained its bactericidal efficacy in a period of 30 days, whereas when PAW was stored at higher temperatures, bactericidal efficacy was lower. No change in $\mathrm{pH}$ and a significant reduction in ORP of PAW after seven days stored at room temperature was also observed by Joshi et al. [35], with a subsequent loss of antibacterial effects. Similarly, plasma activated reverse osmosis water stored at $3{ }^{\circ} \mathrm{C}$ or $24{ }^{\circ} \mathrm{C}$ did not show any difference in $\mathrm{pH}$ values and conductivity after $96 \mathrm{~h}$ storage time [36]. The last studies are in agreement with our study that $\mathrm{pH}$ was found to be stable during the elongated storage time.

An increase of nitrate after one month of storage time at different conditions can also support the scenario that chemical reactions between the detectable ROS and RNS occur and subsequently result in the formation of nitrate. Zhou et al. [37] reported that nitrite can be converted into unstable $\mathrm{HNO}_{2}$ in acidic conditions and subsequent decomposition to other nitric oxide species (reactions 1-3 below). Nitric oxide can diffuse across cellular membranes and exacts nitrosative and oxidative damage on pathogens [38]. Moreover, nitrites can also react with hydrogen peroxide in acidic environment and form peroxynitrite (reaction 4 below) [39]. In this study, nitrite was not detected after plasma treatment time, however it might have been generated during the treatment time and converted to some other RNS.

$$
\begin{gathered}
\mathrm{NO}_{2^{-}}+\mathrm{H}^{+} \longrightarrow \mathrm{HNO}_{2} \\
\mathrm{HNO}_{2}+\mathrm{H}^{+} \longrightarrow \mathrm{NO}^{+}+\mathrm{H}_{2} \mathrm{O} \\
2 \mathrm{HNO}_{2} \longrightarrow \mathrm{NO}+\mathrm{NO}_{2}+\mathrm{H}_{2} \mathrm{O} \\
\mathrm{NO}_{2^{-}}+\mathrm{H}_{2} \mathrm{O}_{2}+\mathrm{H}^{+} \longrightarrow \mathrm{O}=\mathrm{NOOH}+\mathrm{H}_{2} \mathrm{O},
\end{gathered}
$$

Antibacterial studies have indicated peroxynitrite as a crucial factor responsible for the bactericidal potential of PAL. A decrease in the storage temperature could significantly improve the final concentration of peroxynitrite, for instance 2.2 and $4.6 \mu \mathrm{M}$ for $4{ }^{\circ} \mathrm{C}$ and $-16{ }^{\circ} \mathrm{C}$, respectively, over a $24 \mathrm{~h}$ post-discharge period in one study [37]. Based on this statement, we can hypothesize that in our study the concentration of peroxynitrite in PAL might remain higher at lower temperatures such as -80 and $-150^{\circ} \mathrm{C}$ and explain why these solutions could retain their antimicrobial efficacy. According to Kissner et al.'s [40] studies on the dependence of peroxynitrite decay on temperature, $\mathrm{pH}$ and concentration, while peroxynitrous acid ( $\mathrm{pKa} \mathrm{6.8)} \mathrm{isomerizes} \mathrm{to} \mathrm{nitrate,} \mathrm{the} \mathrm{peroxynitrite}$ anion does not. For this reason, all nitrate found was believed to be the product of the isomerization of peroxynitrous acid, a reaction that is first-order in the acid and nearly quantitatively converted to nitrate. The authors reported that at temperature $<5{ }^{\circ} \mathrm{C}$ and $\mathrm{pH}<7$, nitrate was formed with a yield of at least $90 \%$ from low $(50 \mu \mathrm{M})$ or high $(2.5 \mathrm{mM})$ peroxynitrite concentrations [40]. In our study, nitrate measurements generally increased in all PAL tested and could be in accordance with the 
theory suggested by Kissner [40]. Peroxynitrite/peroxynitrous acid is a highly reactive species that gives rise to both oxidative and nitrosative stresses in bacteria. In acidic conditions, peroxynitrous acid can cross the lipid bilayer of the cell membrane of the bacteria cell and then initiate lipid and protein peroxidation and nitration directly or by its decomposition to one-electron oxidants like $\mathrm{OH}$ and $\mathrm{NO}_{2}[41,42]$. The chemical reactions between chemical species and the membrane enhance the permeability of the cell by formation of pores on the membrane in favour of other reactive chemical species penetrating into the cell [43]. While a decomposition of short-lived RNS to more stable species is supported by the increase of nitrate concentrations in all storage conditions, a decrease of nitrates observed between month 1 and 3 is more surprising as nitrate is considered a stable end-product of most RNS decomposition reactions and further analyses to account for all nitrogen in the system are needed. According to Gao et al. [44] the amounts of nitrogenous substances in PAW increased with an increase of treatment time and appeared to follow the order nitrite $<$ ammonium $<$ nitrate. Ammonium was derived from the dissolution of ammonia under acidic conditions, which was synthesized by excited nitrogen and hydrogen in the plasma atmosphere.

Studies of plasma activated media (PAM) reported cytotoxic and genotoxic activity to be retained upon storage at $+4{ }^{\circ} \mathrm{C}$ or $-80^{\circ} \mathrm{C}$ for up to 7 days [45]. PAM were generated by a helium plasma system and stored at different temperature conditions $37^{\circ} \mathrm{C}, 4{ }^{\circ} \mathrm{C},-20^{\circ} \mathrm{C}$ and $-80{ }^{\circ} \mathrm{C}$. The genotoxic activity disappeared in the case of PAM stored of $+37^{\circ} \mathrm{C}$ or $-20^{\circ} \mathrm{C}$, suggesting that hydrogen peroxide concentrations in PAM were stable at $+4{ }^{\circ} \mathrm{C}$ and $-80{ }^{\circ} \mathrm{C}$ while hydrogen peroxide in PAM was decomposed when stored at $+37^{\circ} \mathrm{C}$ and $-20^{\circ} \mathrm{C}$. The explanation given by the authors was that this could be due to the ability of hydrogen peroxide molecules to remain stable at $+4{ }^{\circ} \mathrm{C}$ or at a temperature lower than $-60{ }^{\circ} \mathrm{C}$ leading to crystallization state thus avoiding PAM's chemical decomposition. Thus, crystallisation of hydrogen peroxide may have occurred in these sub-ambient temperatures and prevented degradation/reaction of reactive species in the solutions, thus preserving antimicrobial activity which remained after 18 months.

Interestingly, PAL stored at $-16{ }^{\circ} \mathrm{C}$ was the only liquid stored at sub-zero temperature that did not retain its antimicrobial activity. From a thermodynamic point of view, one of the reasons this happened could be a depression of the freezing point of these solutions, so that there was still (relative) motion of molecules/atoms, thus leading to reaction/degradation of chemical species and antimicrobial instability. But according to Figure 11, this does not hold true, as it was observed that the freezing point of PAW was $-0.1-0{ }^{\circ} \mathrm{C}$, which is close to the untreated controls and nucleation occurred between $-5.7-4.8^{\circ} \mathrm{C}$, similar to the water control. However, hydrogen peroxide does not crystalize until temperatures below $-52{ }^{\circ} \mathrm{C}$, which means that hydrogen peroxide remained in liquid state while water froze out of solution and determined the overall freezing behaviour of the solution, providing a distinct difference between samples stored at $-16^{\circ} \mathrm{C}$ and those at $-80 /-150{ }^{\circ} \mathrm{C}$. While analyses here indicate only small changes to the concentrations of hydrogen peroxide itself, other reactive species may have been present in the liquid phase hydrogen peroxide and been able to undergo reactions prohibited in frozen state.

\section{Conclusions}

In conclusion, the results presented provide a basis for PAL storage and practical applications in disinfection and food preservation. Storing non-buffered PAL at $-80{ }^{\circ} \mathrm{C}$ or $-150{ }^{\circ} \mathrm{C}$ provides a means to retain their bactericidal activity over long-term storage, while caution might be needed when storing PAL in conventional freezers over extended storage time. However, as reactive species composition and concentrations depend on the plasma device, discharge parameters and liquid characteristics, the storage behaviour of plasma activated liquids observed here may not necessarily apply to liquids generated under different conditions. Analyses of reactive species over extended storage highlighted dynamic processes in PAL at all storage temperatures, which warrant further detailed analyses and may be utilized in future to influence chemical reactions in PAL post-plasma exposure. A better understanding of the effects of the temperatures on the chemical species found in 
PAL and subsequent bactericidal effects could lead to an improved classification of PAL in the context of conventional disinfectants.

Supplementary Materials: The following are available online at http://www.mdpi.com/2073-4441/12/11/3021/s1, Table S1: Microbial inactivation of E. coli and S. aureus at 30 and 60 min contact time, treated with PAW or PAS stored at different temperatures for up to 18 months. Table represents averages of 2 independent plasma treatments (Set 1 and 2), Table S2: Microbial inactivation of E. coli and S. aureus at 30 and 60 min contact time, treated with PAW or PAS stored at different temperatures for up to 6 months. Table represents 1 independent plasma treatment (Set 3), Table S3: Microbial inactivation of E. coli and S. aureus at 30 and 60 min contact time, treated with PAW or PAS stored at different temperatures for up to 3 months. Table represents 1 independent plasma treatment (Set 4).

Author Contributions: Conceptualization, E.T., D.B.; methodology, E.T., D.B.; software, E.T., D.B.; validation, D.B.; formal analysis, E.T., D.B.; investigation, E.T., D.B.; resources, D.B.; data curation, D.B.; writing—original draft preparation, E.T., D.B.; writing-review and editing, E.T., D.B., P.B.; visualization, E.T., D.B.; supervision, D.B. and P.B.; project administration, D.B., P.B.; funding acquisition, D.B. All authors have read and agreed to the published version of the manuscript.

Funding: This research was funded by Science Foundation Ireland (SFI), under grant number 15/SIRG/3466.

Conflicts of Interest: The authors declare no conflict of interest.

\section{References}

1. Kampf, G. Acquired resistance to chlorhexidine-Is it time to establish an "antiseptic stewardship" initiative? J. Hosp. Infect. 2016, 94, 213-227. [CrossRef] [PubMed]

2. Verraes, C.; Van Boxstael, S.; Van Meervenne, E.; Van Coillie, E.; Butaye, P.; Catry, B.; de Schaetzen, M.-A.; Van Huffel, X.; Imberechts, H.; Dierick, K.; et al. Antimicrobial resistance in the food chain: A review. Int. J. Environ. Res. Public Health 2013, 10, 2643-2669. [CrossRef] [PubMed]

3. Wand, M.E.; Bock, L.J.; Bonney, L.C.; Sutton, J.M. Mechanisms of Increased Resistance to Chlorhexidine and Cross-Resistance to Colistin following Exposure of Klebsiella pneumoniae Clinical Isolates to Chlorhexidine. Antimicrob. Agents Chemother. 2016, 61, e01162-16. [CrossRef] [PubMed]

4. Carey, D.E.; McNamara, P.J. The impact of triclosan on the spread of antibiotic resistance in the environment. Front. Microbiol. 2015, 5, 780. [CrossRef] [PubMed]

5. Buffet-Bataillon, S.; Tattevin, P.; Bonnaure-Mallet, M.; Jolivet-Gougeon, A. Emergence of resistance to antibacterial agents: The role of quaternary ammonium compounds-A critical review. Int. J. Antimicrob. Agents 2012, 39, 381-389. [CrossRef]

6. Lu, P.; Boehm, D.; Cullen, P.J.; Bourke, P. Controlled cytotoxicity of plasma treated water formulated by open-air hybrid mode discharge. Appl. Phys. Lett. 2017, 110, 264102. [CrossRef]

7. Zhou, R.; Zhou, R.; Yu, F.; Xi, D.; Wang, P.; Li, J.; Wang, X.; Zhang, X.; Bazaka, K.; Ostrikov, K. Removal of organophosphorus pesticide residues from Lycium barbarum by gas phase surface discharge plasma. Chem. Eng. J. 2018, 342, 401-409. [CrossRef]

8. Sarangapani, C.; Ziuzina, D.; Behan, P.; Boehm, D.; Gilmore, B.F.; Cullen, P.J.; Bourke, P. Degradation kinetics of cold plasma-treated antibiotics and their antimicrobial activity. Sci. Rep. 2019, 9, 3955. [CrossRef]

9. Schnabel, U.; Handorf, O.; Stachowiak, J.; Boehm, D.; Weit, C.; Weihe, T.; Schäfer, J.; Below, H.; Bourke, P.; Ehlbeck, J. Plasma-Functionalized Water: From Bench to Prototype for Fresh-Cut Lettuce. Food Eng. Rev. 2020, 1-21. [CrossRef]

10. Lin, C.-M.; Chu, Y.-C.; Hsiao, C.-P.; Wu, J.S.; Hsieh, C.-W.; Hou, C.-Y. The Optimization of Plasma-Activated Water Treatments to Inactivate Salmonella Enteritidis (ATCC 13076) on Shell Eggs. Foods 2019, 8, 520. [CrossRef]

11. Los, A.; Ziuzina, D.; Boehm, D.; Cullen, P.J.; Bourke, P. A Comparison of Inactivation Efficacy and Mechanisms of Gas Plasma and Plasma Activated Water against Aspergillus flavus Spores and Biofilms. Appl. Environ. Microbiol. 2020, 86, e02619-19. [CrossRef]

12. Smet, C.; Govaert, M.; Kyrylenko, A.; Easdani, M.; Walsh, J.; Van Impe, J. Inactivation of Single Strains of Listeria monocytogenes and Salmonella Typhimurium Planktonic Cells Biofilms With Plasma Activated Liquids. Front. Microbiol. 2019, 10, 1539. [CrossRef] [PubMed]

13. Filipić, A.; Gutierrez-Aguirre, I.; Primc, G.; Mozetič, M.; Dobnik, D. Cold Plasma, a New Hope in the Field of Virus Inactivation. Trends Biotechnol. 2020, 38, 1278-1291. [CrossRef] [PubMed] 
14. Perinban, S.; Orsat, V.; Raghavan, V. Nonthermal Plasma-Liquid Interactions in Food Processing: A Review. Compr. Rev. Food Sci. Food Saf. 2019, 18, 1985-2008. [CrossRef]

15. Thirumdas, R.; Kothakota, A.; Annapure, U.; Siliveru, K.; Blundell, R.; Gatt, R.; Valdramidis, V.P. Plasma activated water (PAW): Chemistry, physico-chemical properties, applications in food and agriculture. Trends Food Sci. Technol. 2018, 77, 21-31. [CrossRef]

16. National Research, C. Drinking Water and Health. In Disinfectants and Disinfectant By-Products; The National Academies Press: Washington, DC, USA, 1987; Volume 7.

17. Ng, S.W.; Tsoukou, E.; Chaple, S.; Boehm, D.; Bourke, P. Plasma Treatment of Liquids. In Reference Module in Food Science; Elsevier: Amsterdam, the Netherlands, 2020.

18. Ikawa, S.; Tani, A.; Nakashima, Y.; Kitano, K. Physicochemical properties of bactericidal plasma-treated water. J. Phys. D Appl. Phys. 2016, 49, 425401. [CrossRef]

19. Lukes, P.; Dolezalova, E.; Sisrova, I.; Clupek, M. Aqueous-phase chemistry and bactericidal effects from an air discharge plasma in contact with water: Evidence for the formation of peroxynitrite through a pseudo-second-order post-discharge reaction of $\mathrm{H}_{2} \mathrm{O}_{2}$ and $\mathrm{HNO}_{2}$. Plasma Sources Sci. Technol. 2014, 23, 015019. [CrossRef]

20. Boehm, D.; Heslin, C.; Cullen, P.J.; Bourke, P. Cytotoxic and mutagenic potential of solutions exposed to cold atmospheric plasma. Sci. Rep. 2016, 6, 21464. [CrossRef]

21. Vlad, I.-E.; Anghel, S.D. Time stability of water activated by different on-liquid atmospheric pressure plasmas. J. Electrost. 2017, 87, 284-292. [CrossRef]

22. Traylor, M.J.; Pavlovich, M.; Karim, S.; Hait, P.; Sakiyama, Y.; Clark, D.S.; Graves, D. Long-term antibacterial efficacy of air plasma-activated water. J. Phys. D Appl. Phys. 2011, 44, 472001. [CrossRef]

23. Shen, J.; Tian, Y.; Li, Y.; Ma, R.; Zhang, Q.; Zhang, J.; Fang, J. Bactericidal Effects against S. aureus and Physicochemical Properties of Plasma Activated Water stored at different temperatures. Sci. Rep. 2016, 6, 28505. [CrossRef]

24. Gelinas, P.; Goulet, J.; Tastayre, G.M.; Picard, G.A. Effect of Temperature and Contact Time on the Activity of Eight Disinfectants-A Classification. J. Food Prot. 1984, 47, 841-847. [CrossRef] [PubMed]

25. Tsoukou, E.; Bourke, P.; Boehm, D. Understanding the differences between antimicrobial and cytotoxic properties of plasma activated liquids. Plasma Med. 2018, 8, 299-320. [CrossRef]

26. Moiseev, T.; Misra, N.N.; Patil, S.; Cullen, P.J.; Bourke, P.; Keener, K.; Mosnier, J.P. Post-discharge gas composition of a large-gap DBD in humid air by UV-Vis absorption spectroscopy. Plasma Sources Sci. Technol. 2014, 23, 065033. [CrossRef]

27. Patil, S.; Moiseev, T.; Misra, N.N.; Cullen, P.J.; Mosnier, J.P.; Keener, K.; Bourke, P. Influence of high voltage atmospheric cold plasma process parameters and role of relative humidity on inactivation of Bacillus atrophaeus spores inside a sealed package. J. Hosp. Infect. 2014, 88, 162-169. [CrossRef] [PubMed]

28. Milosavljevic, V.; Cullen, P.J. Spectroscopic investigation of a Dielectric Barrier Discharge in Modified Atmosphere Packaging. Eur. Phys. J. Appl. Phys. 2017, 80, 20801. [CrossRef]

29. Ziuzina, D.; Patil, S.; Cullen, P.J.; Keener, K.; Bourke, P. Atmospheric Cold Plasma Inactivation of Escherichia coli in Liquid Media inside a Sealed Package. J. Appl. Microbiol. 2012, 114, 778-787. [CrossRef]

30. Pan, G.Y.; Chen, C.L.; Chang, H.M.; Gratzl, J.S. Studies on Ozone Bleaching. I. The Effect of PH, Temperature, Buffer Systems and Heavy Metal-Ions on Stability of Ozone in Aqueous Solution. J. Wood Chem. Technol. 1984, 4, 367-387. [CrossRef]

31. Jablonowski, H.; Sousa, J.; Weltmann, K.-D.; Wende, K.; Reuter, S. Quantification of the ozone and singlet delta oxygen produced in gas and liquid phases by a non-thermal atmospheric plasma with relevance for medical treatment. Sci. Rep. 2018, 8, 12195. [CrossRef]

32. Han, L.; Patil, S.; Boehm, D.; Milosavljevic, V.; Cullen, P.J.; Bourke, P. Mechanism of Inactivation by High Voltage Atmospheric Cold Plasma Differs between Escherichia coli and Staphylococcus aureus. Appl. Environ. Microbiol. 2015, 82, 450-458. [CrossRef]

33. Khadre, M.A.; Yousef, A.E.; Kim, J.G. Microbiological Aspects of Ozone Applications in Food: A Review. J. Food Sci. 2001, 66, 1242-1252. [CrossRef]

34. Gorbanev, Y.; O'Connell, D.; Chechik, V. Non-Thermal Plasma in Contact with Water: The Origin of Species. Chemistry 2016, 22, 3496-3505. [CrossRef] [PubMed] 
35. Joshi, I.; Salvi, D.; Schaffner, D.W.; Karwe, M.V. Characterization of Microbial Inactivation Using Plasma-Activated Water and Plasma-Activated Acidified Buffer. J. Food Prot. 2018, 81, 1472-1480. [CrossRef] [PubMed]

36. Figueira, F.; Doria, A.; Khouri, S.; Maciel, H.; Pessoa, R.; Antonio, R.-R. Effect of Storage Temperature on $\mathrm{pH}$ and Conductivity of Reverse Osmosis Water Treated with Atmospheric Plasma. Plasma Med. 2018, 8, 237-244. [CrossRef]

37. Zhou, R.; Zhou, R.; Prasad, K.; Fang, Z.; Speight, R.; Bazaka, K.; Ostrikov, K. Cold atmospheric plasma activated water as a prospective disinfectant the crucial role of peroxynitrite. Green Chem. 2018, 20, 5276-5284. [CrossRef]

38. Schairer, D.O.; Chouake, J.S.; Nosanchuk, J.D.; Friedman, A.J. The potential of nitric oxide releasing therapies as antimicrobial agents. Virulence 2012, 3, 271-279. [CrossRef]

39. Lukes, P.; Locke, B.; Brisset, J.-L. Aqueous-Phase Chemistry of Electrical Discharge Plasma in Water and in Gas-Liquid Environments. In Plasma Chemistry and Catalysis in Gases and Liquids; Parvulescu, P.I., Magureanu, M., Lukes, P., Eds.; John Wiley \& Sons: Hoboken, NJ, USA, 2012; Volume 7, pp. 243-308.

40. Kissner, R.; Koppenol, W. Product Distribution of Peroxynitrite Decay as a Function of pH, Temperature, and Concentration. J. Am. Chem. Soc. 2002, 124, 234-239. [CrossRef]

41. Jia, X.; Chen, Q.; Yang, Y.; Tang, Y.; Wang, R.; Xu, Y.; Zhu, W.; Qian, X. FRET-Based Mito-Specific Fluorescent Probe for Ratiometric Detection and Imaging of Endogenous Peroxynitrite: Dyad of Cy3 and Cy5. J. Am. Chem. Soc. 2016, 138, 10778-10781. [CrossRef]

42. Huie, R.E.; Padmaja, S. The reaction of no with superoxide. Free Radic. Res. Commun. 1993, 18, $195-199$. [CrossRef]

43. Zhang, Q.; Ma, R.; Tian, Y.; Su, B.; Wang, K.; Yu, S.; Zhang, J.; Fang, J. Sterilization Efficiency of a Novel Electrochemical Disinfectant against Staphylococcus aureus. Environ. Sci. Technol. 2016, 50, 3184-3192. [CrossRef]

44. Gao, X.; Zhang, A.; Héroux, P.; Sand, W.; Sun, Z.; Zhan, J.; Cihao, W.; Hao, S.; Li, Z.; Li, Z.; et al. Effect of Dielectric Barrier Discharge Cold Plasma on Pea Seed Growth. J. Agric. Food Chem. 2019, 67, 10813-10822. [CrossRef] [PubMed]

45. Judée, F.; Fongia, C.; Ducommun, B.; Yousfi, M.; Lobjois, V.; Merbahi, N. Short and long time effects of low temperature Plasma Activated Media on 3D multicellular tumor spheroids. Sci. Rep. 2016, 6, 21421. [CrossRef]

Publisher's Note: MDPI stays neutral with regard to jurisdictional claims in published maps and institutional affiliations.

(C) 2020 by the authors. Licensee MDPI, Basel, Switzerland. This article is an open access article distributed under the terms and conditions of the Creative Commons Attribution (CC BY) license (http://creativecommons.org/licenses/by/4.0/). 